\title{
CORRELATION BETWEEN INTERPERSONAL INTELLIGENCE AND LEARNING MOTIVATION TO FIFTH GRADE STUDENTS OF PUBLIC ELEMENTARY SCHOOLS IN KEBUMEN SUB-DISTRICT IN ACADEMIC YEAR OF 2020/2021
}

\author{
Neni Dewi Anggraeni, Rokmaniyah, Suhartono \\ Universitas Sebelas Maret \\ nenidewianggraeni98@gmail.com
}

\section{Article History}

accepted 1/11/2021

\begin{abstract}
Learning is a need. Learning factors consist of intrinsic and extrinsic. Interpersonal intelligence and learning motivation are part of intrinsic factors. The study aimed to analyze and determine the contribution of interpersonal intelligence and learning motivation to fifth grade students of public elementary schools in Kebumen Sub-district in academic year of 2020/2021. It was quantitative method with correlation analysis. The samples were 329 fifth grade students in twelve public elementary schools throughout the Kebumen Sub-district. Sampling method was cluster sampling. Data analysis used simple correlation test (significance level of 5\%) and the determinant coefficient with the help of SPSS 21 Version. The results indicated that there is a positive correlation between interpersonal intelligence. It was strong correlation ( $r$ count $0.618>$ $r$ table 0.18) and significance was $0.000<0.05$. The determinant coefficient was $38 \%$, it meant Interpersonal intelligence contributed $38 \%$ on learning motivation and the remaining $62 \%$ was influenced by other factors.
\end{abstract}

Keywords: interpersonal intelligence, learning motivation

\begin{abstract}
Abstrak
Belajar merupakan kebutuhan. Faktor belajar terdiri dari faktor intrinsik dan ekstrinsik. Kecerdasan interpersonal dan motivasi belajar merupakan bagian dari faktor intrinsik. Motivasi ekstrinsik dipengaruhi oleh rangsangan dari luar memungkinkan kecerdasan interpersonal memegang peranan penting dalam belajar. Penelitian ini bertujuan untuk menganalisis hubungan dan mengetahui sumbangan kecerdasan interpersonal dengan motivasi belajar siswa kelas V SDN se-Kecamatan Kebumen tahun ajaran 2020/2021. Penelitian ini bermetode kuantitatif dengan analisis korelasi. Sampel berjumlah 329 siswa dari 12 sekolah dasar di Kecamatan Kebumen dengan teknik cluster sampling. Analisis data menggunakan uji korelasi sederhana (signifikansi 5\%) dan koefisien determinasi dibantu dengan aplikasi SPSS 21. Hasil penelitian menunjukkan: (1) terdapat hubungan positif antara kecerdasan interpersonal dan motivasi belajar siswa dengan tingkat koefisien korelasi "kuat" ( $r$ hitung 0,618> $r$ tabel 0,108) dan signifikansi $0,000<0,05,(2)$ koefisien determinasi sebesar 38\%, artinya kecerdasan interpersonal memberikan sumbangan hubungan sebesar $38 \%$ dan $62 \%$ sisanya dipengaruhi oleh faktor lain.
\end{abstract}

Kata kunci: Kecerdasan Interpersonal, Motivasi Belajar 


\section{PENDAHULUAN}

Belajar merupakan kebutuhan bagi setiap manusia. Pane dan Dasopang (2017) menyatakan belajar adalah proses perubahan pemahaman dan tingkah laku, yang bermula pada potensi alami tanpa ilmu pengetahuan menuju arah yang lebih baik. Selain itu, Santoso dan Subagyo (2017) menyatakan belajar merupakan proses yang terjadi pada semua orang untuk mendapatkan perubahan tingkah laku secara kognitif (pengetahuan), afektif (sikap) dan psikomotorik (keterampilan) yang berlangsung tanpa henti. Dari dua pendapat tersebut dapat dimengerti bahwa belajar adalah proses perubahan tingkah laku dan pemahaman ke arah yang lebih baik bagi setiap orang dari keadaan belum tahu menjadi tahu yang mencakup ranah kognitif (pengetahuan), afektif (sikap) dan psikomotorik (keterampilan) secara terus-menerus. Di dalam prosesnya, belajar memiliki faktor-faktor yang memengaruhi.

Faktor-faktor yang memengaruhi keberhasilan proses belajar terbagi menjadi dua, yaitu faktor internal dan faktor eksternal. Faktor internal yaitu faktor dari dalam diri peserta didik meliputi bakat (aptitude), kondisi fisik, motivasi, keterampilan (kecakapan), minat, kecerdasan, dan mental, sedangkan faktor eksternal yaitu faktor dari dalam luar peserta didik meliputi lingkungan (alam, sosial, dan sekolah), keluarga dan masyarakat yang ditinjau dari keadaan sosio ekonomis, sosio kultural serta keadaan masyarakat (Hartaya \& Lasrin, 2015).

Dari dua faktor di atas, terdapat dua aspek faktor internal yang penting dalam memengaruhi keberhasilan belajar, yaitu motivasi dan kecerdasan interpersonal. Menurut Bastari (2019) motivasi belajar adalah daya dorongan atau penggerak yang memberikan semangat dan arah belajar dalam diri peserta didik, sehingga tujuan dapat tercapai. Ningrat dan Sumantri (2018) menyatakan motivasi belajar adalah dorongan dari dalam maupun luar diri peserta didik untuk belajar, sehingga terjadi perubahan tingkah laku untuk mencapai tujuan dengan didukung harapan, cita-cita, lingkungan, penghargaan, kebutuhan dan keinginan untuk mencapai sesuatu. Berdasarkan pendapat tersebut, disimpulkan motivasi belajar adalah dorongan, daya penggerak atau kekuatan yang berasal dari dalam (intrinsik) atau luar diri (ekstrinsik) setiap peserta didik untuk melakukan aktivitas belajar dengan penuh semangat, sehingga prestasi belajar dapat tercapai. Indikator motivasi belajar meliputi tekun menghadapi tugas, tidak mudah putus asa atau ulet menghadapi masalah, menunjukkan minat dalam belajar, berprestasi dalam belajar, mandiri dalam belajar, cepat bosan dengan tugas rutin, dan senang memecahkan masalah, sedangkan kecerdasan interpersonal adalah kemampuan yang dimiliki oleh seseorang dalam menciptakan hubungan dengan orang lain melalui komunikasi, pemahaman perasaan, bekerja sama, memotivasi, dan berempati, sehingga setiap individu mampu memberikan tanggapan yang sesuai dengan kondisi yang dihadapi. Indikator kecerdasan interpersonal meliputi membangun hubungan sosial, sikap empati, sikap prososial, keterampilan pemecahan masalah, keterampilan berbicara efektif, dan keterampilan mendengarkan efektif. Di dalam prosesnya kecerdasan interpersonal dapat ditampakan dengan kegembiraan dan kesenangan dalam beraktifitas sosial. Anak yang tingkat kecerdasan interpersonalnya tinggi menyukai dan menikmati bekerja berkelompok termasuk dalam proses belajar baik di rumah atau sekolah (Jasmine, 2007). Pada dasarnya, setiap peserta didik sudah dibekali dengan kecerdasan interpersonal. Namun, setiap siswa memiliki tingkat kecerdasan interpersonal yang berbeda-beda. Disisi lain setiap siswa juga memiliki perbedaan motivasi belajar.

Survey dan wawancara terhadap guru kelas V SDN 1 Panjer, terdapat penurunan motivasi belajar yang disebabkan oleh kurangnya interaksi anak dalam bersosialisasi selama pembelajaran daring. Hal ini karena ruang gerak anak untuk berinteraksi dengan orang lain dibatasi. Berdasarkan penuturannya, terdapat empat sampai lima siswa kelas $\mathrm{V}$ yang pasif untuk bersosialisasi antarpribadi saat belajar. Jumlah siswa yang pasif ini sama dengan jumlah siswa yang pasif di Kelas V SDN 1 
Kebumen. Selain itu, pada anak dengan kecerdasan interpersonal yang tinggi merasa kurang termotivasi belajar karena ruang interaksi dibatasi, sedangkan pada anak dengan kecerdasan interpersonal yang rendah, kurang termotivasi belajar karena kurangnya rangsangan dari luar. Hal ini diketahui dari 34 siswa di SDN 1 Panjer, sebanyak 29 siswa dengan kecerdasan interpersonal tinggi kurang termotivasi belajar karena ruang interaksi dibatasi, sedangkan 14 siswa dengan kecerdasan interpersonal yang rendah kurang termotivasi belajar karena kurangnya rangsangan dari luar. Pernyataan sama juga dikemukakan dari guru kelas V SDN 1 Kebumen yang mana dari 40 siswa sebanyak 35 siswa memiliki kecerdasan interpersonal tinggi dan 5 yang memiliki kecerdasan interpersonal rendah kurang termotivasi belajar karena ruang gerak dibatasi. Pengaruh lainnya tampak pada rasa senang ketika anak melakukan PTS secara berkelompok pada sesi home visiting yang dilakukan guru kelas, siswa timbul inisiatif untuk menghampiri siswa yang belum datang untuk PTS bersama. Hal ini menunjukkan kemungkinan adanya hubungan antara kecerdasan interpersonal dengan motivasi belajar pada siswa kelas V. Guru juga menuturkan bahwa terdapat perbedaan motivasi belajar antara pembelajaran secara daring dan luring berupa penurunan motivasi untuk belajar yang terlihat dari anak yang lebih suka bermain dibandingkan dengan belajar. Dari sisi proses pembelajaran, Guru merasa kebingungan untuk melaksanakan model dan metode pembelajaran yang sesuai karena keterbatasan ruang gerak untuk belajar karena wilayah kecamatan Kebumen yang masih zona merah, sehingga tidak memungkinkan untuk bertatap muka atau memberikan tugas secara berkelompok. Beberapa aspek kegiatan belajar yang melibatkan interaksi antarpeserta didik seperti, kerja sama, diskusi, tanya jawab dan saling menanggapi menjadi terhambat. Tentunya hal ini membuat pembelajaran kurang optimal dan motivasi belajar menjadi berkurang.

Berdasarkan uraian di atas, peneliti tertarik untuk meneliti hubungan kecerdasan interpersonal dan motivasi belajar peserta didik pada jenjang sekolah dasar kelas V. Selain karena penelitian ini masih jarang diteliti pada jenjang sekolah dasar, penelitian juga ini bertujuan untuk menganalisis dan mengetahui besarnya sumbangan kecerdasan interpersonal terhadap motivasi belajar siswa kelas V SDN seKecamatan Kebumen pada tahun ajaran 2020/2021.Penelitian ini diharapkan menjadi perhatian bagi guru atau orang tua agar meningkatkan motivasi belajar dengan memperhatikan aspek kecerdasan interpersonal yang dimiliki setiap peserta didik agar kebermaknaan belajar dapat tercapai dengan baik.

\section{METODE}

Penelitian ini merupakan penelitian kuantitatif korelasional. Penelitian korelasi yaitu penelitian untuk mengetahui hubungan antara dua variabel yang diteliti (Priyatno, 2012). Peneliti menetapkan kecerdasan interpersonal sebagai variabel independen dan motivasi belajar sebagai variabel dependen untuk dicari korelasi dan sumbangan korelasi diantara kedua variabel.

Sampel penelitian diambil dari populasi siswa kelas V SDN se-Kecamatan Kebumen tahun ajaran 2020/2021 yang berjumlah 1554 siswa yang dipilih acak dengan teknik cluster sampling dari 56 sekolah dasar, sehingga diperoleh sampel siswa sebanyak 329 dari 12 sekolah dasar. Di dalam prosesnya penelitian ini dibantu dengan aplikasi Statistical Product and Service Solution (SPSS) versi 21 untuk menghasilkan data yang dibutuhkan.

Teknik pengumpulan data menggunakan angket pada kedua variabel. Instrumen penelitian disusun berdasarkan indikator yang ditetapkan. Kriteria skala angket menggunakan jenis skala likert yang terdiri dari opsi sangat setuju, setuju, tidak setuju dan sangat tidak setuju (Sukardi,2012).

Sebelum digunakan angket diuji validitas dan reliabilitas untuk mendapatkan instrument yang berkualitas saat penelitian. Uji prasyarat analisis data menggunakan 
uji linieritas dan uji normalitas. Setelah memenuhi prasyarat data dianalisis dengan uji korelasi sederhana untuk mengetahui hubungan kedua variabel dan perhitungan koefisien determinasi untuk mengetahui sumbangan hubungan kedua variabel.

\section{HASIL DAN PEMBAHASAN}

Data yang digunakan dalam penelitian ini merupakan data berasal dari skor angket motivasi belajar dan skor angket kecerdasan interpersonal siswa kelas V SDN se-Kecamatan Kebumen.Data yang diolah dengan SPSS 21.

1. Deskripsi Data

a. Variabel Kecerdasan Interpersonal

Tabel 1 Distribusi Kecerdasan Interpersonal Kriteria/Klasifikasi Penilaian Kecerdasan Interpersonal

\begin{tabular}{cccccc}
\hline \multirow{2}{*}{ Kalid } & Kriteria & Frequency & $\begin{array}{c}\text { Percent } \\
\text { (\%) }\end{array}$ & $\begin{array}{c}\text { Valid } \\
\text { Percent }\end{array}$ & $\begin{array}{c}\text { Cumulative } \\
\text { Percent }\end{array}$ \\
\hline \multirow{6}{*}{ Tinggi } & 41 & 12.5 & 12.5 & 12.5 \\
& Sedang & 243 & 73.9 & 73.9 & 86.3 \\
& Rendah & 45 & 13.7 & 13.7 & 100.0 \\
& TOTAL & 329 & 100 & 100 & \\
\hline
\end{tabular}

Berdasarkan tabel di atas siswa dengan kriteria rendah sebanyak 45 $(13,7 \%)$, siswa dengan kriteria sedang sebanyak $243(73,9 \%)$ dan siswa dengan kriteria tinggi sebanyak $41(12,5 \%)$, sehingga kecenderungan kecerdasan interpersonal siswa kelas V SDN di Kecamatan Kebumen berada pada kriteria sedang.

b. Variabel Motivasi Belajar

Tabel 2 Distribusi Motivasi Belajar

Kriteria/Klasifikasi Motivasi Belajar

\begin{tabular}{cccccc}
\hline \multirow{2}{*}{ Valid } & Kriteria & Frequency & $\begin{array}{c}\text { Percent } \\
\text { (\%) }\end{array}$ & $\begin{array}{c}\text { Valid } \\
\text { Percent }\end{array}$ & $\begin{array}{c}\text { Cumulative } \\
\text { Percent }\end{array}$ \\
& Tinggi & 57 & 17.3 & 17.3 & 17.3 \\
& Sedang & 223 & 67.8 & 67.8 & 85.1 \\
& Rendah & 49 & 14.9 & 14.9 & 100.0 \\
& TOTAL & 329 & 100 & 100 & \\
\hline
\end{tabular}

Berdasarkan tabel di atas siswa dengan kriteria rendah sebanyak 49 $(14,9 \%)$, siswa dengan kriteria sedang sebanyak $223(67,8 \%)$ dan siswa dengan kriteria tinggi sebanyak $57(17,3 \%)$, sehingga kecenderungan motivasi belajar siswa kelas V SDN di Kecamatan Kebumen berada pada kriteria sedang.

2. Hasil Uji Prasyarat Analisis Data

\section{a. Uji Normalitas Data}

Uji normalitas dilakukan untuk mengetahui apakah data yang berasal dari populasi yang berdistribusi normal atau tidak. 
Tabel 3 Hasil Analisis Uji Normalitas Variabel Motivasi Belajar

One-Sample Kolmogorov-Smirnov Test

\begin{tabular}{lrr}
\hline & Motivasi Belajar & $\begin{array}{c}\text { Kecerdasan } \\
\text { Interpersonal }\end{array}$ \\
\hline$N$ & 329 & 329 \\
Kolmogorov-Smirnov Z & 1.273 & .999 \\
Asymp. Sig. (2-tailed) & .078 & .271 \\
\hline
\end{tabular}

Berdasarkan tabel 3 nilai signifikansi motivasi belajar sebesar 0,078 dan kecerdasan interpersonal 0,271 , sehingga kedua variabel berasal dari populasi yang normal atau terima $\mathrm{H}_{0}$ karena Sig. $>\alpha(0,05)$.

b. Uji Linieritas Data

Linieritas adalah asumsi adanya hubungan dalam bentuk garis lurus antara variabel yang diteliti.

Tabel 4 Hasil Uji Linieritas Angket Kecerdasan Interpersonal dan Motivasi Belajar

ANOVA Table

\begin{tabular}{|c|c|c|c|c|c|}
\hline & & & $\begin{array}{l}\text { Mean } \\
\text { Square }\end{array}$ & $F$ & Sig \\
\hline \multirow{4}{*}{$\begin{array}{l}\text { Motivasi } \\
\text { Belajar } \\
\text { Kecerdasan } \\
\text { Interpersonal }\end{array}$} & & (Combined) & 194.657 & 7.483 & .000 \\
\hline & Between & Linearity & 5446.743 & 209.395 & .000 \\
\hline & * Groups & $\begin{array}{l}\text { Deviation from } \\
\text { Linearity }\end{array}$ & 35.503 & 1.365 & .094 \\
\hline & $\begin{array}{l}\text { Within } \\
\text { Groups }\end{array}$ & & 26.012 & & \\
\hline
\end{tabular}

Berdasarkan tabel 4 nilai Sig. Deviation from Linearity sebesar 0,94, Sig. Deviation from Linearity $>\alpha(0,05)$, maka $\mathrm{H}_{0}$ diterima atau terdapat hubungan linier antara kecerdasan interpersonal dan motivasi belajar siswa kelas $\mathrm{V}$.

\section{Hasil Uji Analisis dan Hipotesis Data}

\section{a. Analisis Korelasi Sederhana}

Tabel 5 Hasil Analisis Korelasi Kecerdasan Interpersonal dan Motivasi Belajar

\begin{tabular}{llrr}
\multicolumn{4}{c}{ Correlations } \\
\hline & $\begin{array}{c}\text { Kecerdasan } \\
\text { Interpersonal }\end{array}$ & $\begin{array}{c}\text { Motivasi } \\
\text { Belajar }\end{array}$ \\
\hline Kecerdasan & Pearson Correlation & 1 & $.618^{* *}$ \\
Interpersonal & Sig. (2-tailed) & & .000 \\
& $\mathrm{~N}$ & 329 & 329 \\
Motivasi & Pearson Correlation & $.618^{* *}$ & 1 \\
Belajar & Sig. (2-tailed) & .000 & 329 \\
\hline
\end{tabular}

Berdasarkan tabel 5 nilai signifikansi (2 -tailed) $0,000<0$, 05 berarti $\mathrm{H}_{0}$ ditolak, sehingga ada hubungan positif antara kecerdasan interpersonal dan motivasi belajar siswa kelas $\mathrm{V}$ SDN se-Kecamatan Kebumen, sedangkan koefisien korelasi $r$ hitung sebesar 0,618 , sedangkan $r$ tabel $(d f=327)$ yaitu 0,108 , maka nilai $r$ hitung $(0,618)>r$ tabel $(0,108)$ artinya terdapat hubungan yang kuat. Hal ini sejalan dengan pedoman interpretasi koefisien korelasi versi 
De Veus (Alaydrus dan Hardjomuljadi, 2018) bahwa rentang koefisien 0,50 0,69 memiliki kekuatan korelasi yang kuat. Oleh karena itu, hipotesis yang menyatakan ada hubungan positif antara kecerdasan interpersonal dan motivasi belajar siswa kelas $\mathrm{V}$ SDN se-Kecamatan Kebumen tahun ajaran 2020/2021 dapat diterima.

Hasil penelitian ini sesuai dengan penelitian Muthmainnah (2019) yang menyatakan terdapat hubungan positif dan signifikan antara kecerdasan interpersonal dan motivasi belajar dan diperkuat dengan pendapat Trevino (2020) yang mendefinisikan kecerdasan interpersonal sebagai kemampuan untuk memahami maksud, motivasi, dan keinginan orang lain dan pendapat Masfiroh (Wijaya, 2018) menyatakan kecerdasan interpersonal adalah kecerdasan yang dimiliki seorang anak dalam memahami dan menanggapi secara tepat suasana hati, keinginan orang lain dan motivasi, sehingga anak yang terlibat interaksi mampu berkomunikasi dengan baik, memiliki rasa simpati dan mendidik orang lain. Adanya unsur motivasi dalam definisi tersebut menunjukkan terdapat hubungan antara kecerdasan interpersonal dan motivasi belajar siswa, sehingga ragam teori adanya hubungan dua variabel ini dapat diterima.

\section{b. Analisis Koefisien Determinan}

Koefisien determinan merupakan ukuran yang menyatakan besarnya sumbangan hubungan variabel $X$ terhadap $Y$ dalam sebuah analisis korelasi (Riduwan, 2019). Koefisien determinan dihitung dengan mengalikan $r$ hitung dengan angka 100\% (KP = $\left.r^{2} \times 100 \%\right)$ (Riduwan \& Sunarto, 2013).

$$
\begin{aligned}
\mathrm{KP} & =r^{2} \times 100 \% \\
& =0,618^{2} \times 100 \% \\
& =38 \%
\end{aligned}
$$

Berdasarkan perhitungan dan tabel 5 , nilai koefisien determinasi atau $r$ hitung sebesar 0,618. Hasil tersebut kemudian digunakan untuk mencari koefisien determinan dengan hasil sebesar 38\% yang artinya kecerdasan interpersonal dapat berperan menjadi salah satu kontributor untuk meningkatkan motivasi belajar dengan sumbangan sebesar $38 \%$, sedangkan $62 \%$ lainnya disumbang oleh faktor atau variabel lainnya yang tidak diteliti. Hal ini dapat dikaitkan dengan pendapat Kompri (Emda, 2017) bahwa faktor yang memengaruhi motivasi belajar yaitu cita-cita, kemampuan siswa, kondisi siswa. Pendapat Sabrina, Fauzi, dan Yamin (2017) yaitu kondisi lingkungan siswa, dan upaya guru dalam pembelajaran. Selain itu, Baralihan (2015) menyatakan variabel lain yang bisa menjadi penyumbang motivasi belajar meliputi faktor internal yaitu keadaan fisik dan psikis, minat, ekspektasi dan nilai, tujuan, atribusi, faktor emosional, dan faktor eksternal yang meliputi motif sosial, ekspektasi dan atribusi guru, gender, sosial ekonomi, konteks sosial budaya.

\section{SIMPULAN}

Berdasarkan hasil penelitian dan pembahasan maka simpulan sebagai berikut:

1. Kecerdasan interpersonal berkorelasi positif dengan motivasi belajar siswa kelas $\mathrm{V}$ SDN se-Kecamatan Kebumen tahun ajaran 2020/2021 dengan tingkat korelasi kuat yaitu 0, 618 yang artinya semakin tinggi kecerdasan interpersonal yang dimiliki siswa, maka semakin tinggi motivasi belajar yang dimiliki siswa. Begitu pula sebaliknya.

2. Sumbangan hubungan kecerdasan interpersonal terhadap motivasi belajar sebesar $38 \%$, sedangkan $62 \%$ dipengaruhi faktor lain yang tidak diteliti yaitu citacita, kemampuan siswa, kondisi siswa, kondisi lingkungan siswa, upaya guru 
dalam pembelajaran, faktor internal (keadaan fisik, psikis, minat, ekspektasi, nilai, tujuan, atribusi, faktor emosional), dan faktor eksternal (motif sosial, ekspektasi dan atribusi guru, gender, sosial ekonomi, konteks sosial budaya).

Implikasi penelitian ini terdapat hubungan yang positif antara dua variabel. Kecerdasan interpersonal memberikan sumbangan terhadap peningkatan motivasi belajar. Oleh karena itu, sangat penting guru mengenali tingkat kecerdasan interpersonal setiap siswa. Guru diharapkan menerapkan strategi pembelajaran inovatif interaktif yang melibatkan kerjasama tim atau kooperatif seperti jigsaw, group investigation, team group tournament, dan STAD sehingga meningkatkan kecerdasan interpersonal yang dimiliki siswa. Bagi sekolah, sebaiknya memberikan pengertian kepada orang tua pentingnya kecerdasan interpersonal dan motivasi belajar, sehingga dorongan belajar juga berasal orang tua. Bagi peneliti selanjutnya diharapkan menjadi referensi.

\section{DAFTAR PUSTAKA}

Alaydrus, A. M., \& Hardjomuljadi, S. (2018). Analisis Faktor Keterlambatan Dimulainya Pelaksanaan Proyek Konstruksi pada Model Kontrak Rancang Bangun. Jurnal Konstruksia, volume 10 no 1 halaman 95-116. Diperoleh pada 29 Desember 2020, dari http://jurnal.umj.ac.id.

Baralihan, T. (2015). Hubungan antara Intensitas Komunikasi Interpersonal dengan Motivasi Belajar. Skripsi Fakultas Psikologi Universitas Muhammadiyah Surakarta. Diperoleh 10 Juni 2021, dari https://eprints.ums.ac.id.

Bastari, E. (2019). Hubungan Motivasi Belajar dengan Hasil Belajar Peserta Didik Pada Mata Pelajaran IPS Kelas IV SD Negeri 1 Sukabumi Indah Bandar Lampung Tahun 2018/2019. Skripsi Pendidikan Guru Madrasah Ibtidaiyah Fakultas Tarbiyah dan Keguruan Universitas Islam Negeri Raden Intan Lampung. Diperoleh 20 Oktober 2020, dari http://repository.radenintan.ac.id.

Emda, A. (2017). Kedudukan Motivasi Belajar Siswa dalam Pembelajaran. Lantanida Journal, volume 5 nomor 2 (2017) 93-196. Diperoleh 20 Oktober 2020, dari http://jurnal.ar-raniry.ac.id.

Hartaya, K. \& Lasrin H. (2015). Hubungan Antara Kecerdasan Interpersonal dan Motivasi Belajar Siswa dengan Hasil Belajar Fisika (Survei pada Peserta Didik Kelas X di SMA Kosgoro Bogor). Jurnal Teknologi Pendidikan. Program Studi Teknologi Pendidikan. Fakultas Pascasarjana. UIKA. Bogor volume 4 nomor 1 tahun 2015. Diperoleh 20 Oktober 2020, dari http://ejournal.uika-bogor.ac.id.

Jasmine, J. (2007). Mengajar dengan Metode Kecerdasan Majemuk (Implementasi Multiple Intellegences). Cetakan 1. Bandung: Nuansa.

Muthmainnah, F. (2019). Hubungan Kecerdasan Intrapersonal dan Interpersonal Melalui Mediasi Iklim Kelas dengan Motivasi Belajar Siswa pada Pembelajaran Tematik di Madrasah Ibtidaiyah Negeri (MIN) 2 Kota Malang. Tesis Program Magister Pendidikan Guru Madrasah Ibtidaiyah Pascasarjana Universitas Islam Negeri (UIN) Maulana Malik Ibrahim Malang 2019. Diperoleh 20 Oktober 2020, dari http://etheses.uin-malang.ac.id.

Ningrat, S. P., \& Sumantri, M. (2018). Kontribusi Gaya Belajar dan Motivasi Belajar Terhadap Hasil Belajar Bahasa Indonesia Siswa Kelas V SD. Sayu, Sumantri (2018). Journal of Education Technology, volume 2 (4) pp. 145-152. Diperoleh 12 November 2020, dari https://ejournal.undiksha.ac.id.

Pane, A. \& Dasopang, M. D. (2017). Belajar dan Pembelajaran. FITRAH: Jurnal Kajian IImu-IImu Keislaman volume 03 nomor 2 Desember 2017 E-ISSN: 2460 2345, P-ISSN: 2442-6997. Diperoleh 20 Oktober 2020, dari http://jurnal.iainpadangsidimpuang.ac.id.

Priyatno, D. (2012). Belajar Cepat Olah Data Statistik dengan SPSS. Yogyakarta: C. V Andi Offset. 
Riduwan. (2019). Belajar Mudah Penelitian untuk Guru - Karyawan dan Peneliti Pemula. Cetakan ke-11. Bandung: Alfabeta.

Riduwan \& Sunarto. (2013). Pengantar Statistika untuk Penelitian Pendidikan, Sosial, Ekonomi, Komunikasi dan Bisnis. Cetakan ke-7. Bandung: Alfabeta.

Sabrina, R., Fauzi, \& Yamin, M. (2017). Faktor-Faktor Penyebab Rendahnya Motivasi Belajar Siswa dalam Proses Pembelajaran Matematika di Kelas V SD Negeri Garot Geuceu Aceh Besar. Jurnal IImiah Pendidikan Guru Sekolah Dasar FKIP Unsyiah, volume 2 nomor 4, 108-118 Desember 2017. Diperoleh 20 Oktober 2020, dari http://www.jim.unsyiah.ac.id/pgsd/article/view/7736.

Santoso, H. B. \& Subagyo. (2017). Peningkatan Aktifitas dan Hasil Belajar dengan Metode Problem Basic Learning (PBL) pada Mata Pelajaran Tune Up Motor Bensin Siswa Kelas XI di SMK Insan Cendekia Turi Sleman Tahun Ajaran 2015/2016. Jurnal Taman Vokasi volume 5 nomor 1, Juni 2017. Diperoleh 20 Oktober 2020, dari http://jurnal.ustjogja.ac.id.

Sukardi. (2012). Metodologi Penelitian Pendidikan: Kompetensi dan Praktiknya. Jakarta: Bumi Aksara.

Trevino, I. M. G., dkk. (2020). Assesment of Multiple Intelligences in Elementary School Student in Mexico: An Exploratory Study. Heliyon Journal 6 (2020) e03777. Diperoleh 9 Desember 2020, dari http://sciencedirect.com.

Wijaya, I. K. W. B. (2018). Mengembangkan Kecerdasan Majemuk Siswa Sekolah Dasar (SD) Melalui Pembelajaran IPA untuk Meningkatkan Mutu Lulusan Sekolah Dasar. Jurnal Penjaminan Mutu, volume 4 nomor 2 Agustus 2018 ISSN: 2407-912X (Cetak) ISSN: 2548-3110 (Online). Diperoleh 12 November 2020, dari http://ejournal.ihdn.ac.id/index.php/JPM. 